\title{
The ideology of ageism versus the social imaginary of the fourth age: two differing approaches to the negative contexts of old age
}

\author{
Paul Higgs ${ }^{1 \star}$ and Chris Gilleard ${ }^{1}$ \\ ${ }^{1}$ Division of Psychiatry, Faculty of Brain Sciences, University College London, London, UK \\ ${ }^{\star}$ Corresponding author. Email: p.higgs@ucl.ac.uk
}

(Accepted 3 January 2019; first published online 6 March 2019)

\begin{abstract}
The development of social gerontology has led to the emergence of its own terminology and conceptual armoury. 'Ageism' has been a key concept in articulating the mission of gerontology and was deliberately intended to act as an equivalent to the concepts of racism and sexism. As a term, it has established itself as a lodestone for thinking about the devalued and residualised social status of older people in contemporary society. Given this background, ageism has often been used to describe an overarching ideology that operates in society to the detriment of older people and which in large part explains their economic, social and cultural marginality. This paper critiques this approach and suggests an alternative based upon the idea of the social imaginary of the fourth age. It argues that not only is the idea of ageism too totalising and contradictory but that it fails to address key aspects of the corporeality of old age. Adopting the idea of a social imaginary offers a more nuanced theoretical approach to the tensions that are present in later life without reducing them to a single external cause or explanation. In so doing, this leaves the term free to serve, in a purely descriptive manner, as a marker of prejudice.
\end{abstract}

Keywords: ageism; ideology; fourth age; social imaginary; ageing body

\section{Introduction}

The development of social gerontology has led to the emergence of its own terminology and conceptual armoury. Alongside terms such as 'disengagement', 'structured dependency' and 'successful ageing', 'ageism' has been a key tool in articulating the mission of gerontology. Introduced by Robert Butler in 1969, ageism was intended to act as an equivalent to the concepts of racism and sexism that were being articulated by the emerging social movements of the time (Palmore and Manton, 1973). Ageism has since established itself as a lodestone for thinking about the social categorisation of older people and the reasons for their de-valued and residualised status in contemporary society. Many commentators have identified 
agedness as a source of discrimination, as when an often arbitrarily designated chronological age is used to treat older people as 'figures of fun and ridicule' (Neuberger, 2009: 106). Alongside what Butler considered the low value accorded to old age and the negative stereotyping of older people, he also identified discriminatory institutional processes as a component part of ageism that further worsened the position of older people (Butler, 1969). How ageism functions and what fundamentally underpins it continues to be a topic of ongoing debate within the field of social gerontology (Coupland and Coupland, 1993; Greenberg et al., 2002; Bytheway, 2005; Snellman, 2016).

Within these discussions, some have made a much stronger argument to the effect that 'ageism' operates as an overarching ideology that serves to devalue older people and which in large part explains their economic, social and cultural marginality in society (Bytheway, 1994). Others such as Macnicol have been somewhat less categorical, seeing ageism as a multifaceted phenomenon which can certainly lead to negative discrimination but which also justifies the existence of various age-related benefits and mandatory retirement pensions (Macnicol, 2006, 2015). Behind this latter position lies less of an interest in the processes of ageism than a concern to use the term as a legal weapon in challenging unfair acts of discrimination towards older people. Yet another group is mainly concerned with how negative stereotypes of old age can both stigmatise and discriminate against older people in ways that can be overcome if the issue is addressed by challenging these ageist assumptions (Chiu et al., 2001; Levy, 2001). Despite the many different articulations of what is meant by the term 'ageism', the term itself, or variants such as 'ageist discourse' or 'ageist ideology', are often used in combination, becoming in effect equivalent and interchangeable concepts. Part of the reason for this lack of clarity in definitions and overlap in explanatory function is the desire to make ageism a source of oppression equal to other acknowledged oppressions - complete with its own history of contestation and struggle (Ray et al., 2009; Gullette, 2017a). For such a strategy to work effectively the more ageism can be identified as an ideology, the greater its general explanatory value would seem to be. In this stronger formulation, ageism may emerge as a product of attitudes or prejudice, but can also be combined into representing one aspect of an inherently discriminatory society or culture. Such structural discrimination links disadvantageous employment practices and social policies to the oppressions of institutional abuse, the 'segregation' of old people as well as the negative stereotyping of old age. Margaret Gullette, who has been very influential in setting an agenda on ageism through her book Agewise (Gullette, 2011) has in her more recent work gone so far as to identify ageism as 'trauma' threatening older people 'with palpable violence' (Gullette, 2017a: 14). Consequently, while quite a few other writers might hesitate to engage with the totality of uses to which ageism as an ideology has been put, most would recognise that making links between the individual and the societal facilitates both social critique and political engagement.

In this paper, we want to challenge the ubiquity of 'ageism' as a catch-all concept capable of explaining the discrimination faced by older people. Instead, we wish to advance the argument that the corporeality of the ageing body is underplayed in the reconfiguration of agedness as an 'ideological' trope. In a number of works we have posited a more culturally reflexive approach to contemporary ageing; one which we 
think affords more insight into the dialectic of age (Gadow, 1983) than does a reliance on the idea of ageism as ideology (Gilleard and Higgs, 2010; Higgs and Gilleard, 2015). In particular, we argue that later life has become framed through two very different but closely interconnected concepts, namely those of the third age and fourth age. Put at the centre of analysis, this bifurcation between an 'aspirational' and a 'feared' later life avoids some of the more obvious contradictions that have beset the 'ageism as ideology' approach, as noted for example by Longino (2005). Central to this reformulation is the separation of the socio-structural circumstances of later life from the cultural. This allows us to explain both the advances that have been made in the material improvement in older people's lives, as well as the devaluation of agedness that can be identified in much contemporary culture. Shifting the focus from ageism as a generalising structure to one concentrating on the interplay between the cultures of a third age and the social imaginary of a fourth, however, does not obviate concerns about experiences of 'unequal ageing'. The impact of health inequalities and poverty still retains importance, but in this new perspective these phenomena can be studied as features of a more widely distributed set of social inequalities, realised at different times and in different ways across the whole of the lifecourse (Gilleard and Higgs, 2016).

Critiques of social processes employing ageism as a lens have generally incorporated simple age-based distributional inequalities with concerns regarding the civic exclusion and cultural devaluation of older persons. Indeed, the European Union (EU) Horizon 2020 programme has organised a number of initiatives specifically on the topic of ageism, including the 'EuroAgeism' international training network which identifies as its prime concern the "high prevalence of ageism; the complex and often negative construction of old age' within Europe (https://cordis.europa.eu/ project/rcn/211870_en.html). A similar EU initiative, the 'COST Action on Ageism' also identifies the high prevalence of ageism and the 'unequivocal evidence concerning the negative consequences associated with ageism at the individual, familial, and societal levels' (http://www.cost.eu/COST_Actions/isch/IS1402). These concerns encompass an ever-widening range of phenomena, from restricted access to specific health resources to various forms of gendered age-based exclusion within contemporary culture and society.

Ageism research has also become more focused on the body and its representation. One contributor to the book Unequal Ageing commented: 'The fading body is derided, mocked in an attempt to distance the unacceptable truth of ageing' (Appleyard, 2009: 126). This turn towards the body has had the effect of re-orientating studies of ageism towards concerns over stereotypes and the internalisation of psycho-social representations (Wilkinson and Ferraro, 2002) with less concern as to how, as Pickard (2016) describes it, the 'age system' works. Again, while many writers using the concept of ageism might not evince such a totalising view of the concept, it is also the case that they rarely criticise its extension to wider aspects of the lives of older people. In her most recent book, Ending Ageism, or How Not to Shoot Old People, Gullette focuses on the way that bodily ageing is not only subject to 'age shaming' but is itself a product of a 'decline ideology' (2017a: 192) which calls for a political response, articulated in her much publicised 'declaration of grievances' (2017a: 205-206). While it might be regarded as unrepresentative to single out the work of one author, we would argue that from a variety of positions a 
consensus has built up around the idea that ageism constitutes an oppressive ideology pervading contemporary society. Even if this recognition is not fully elaborated or even rendered theoretically consistent, it has captured the imagination of many of those working in the field of social gerontology and ageing studies as well as those promoting policies for an 'ageing society'. While there are undoubted variations in how aspects of ageism can be understood, we would argue that this broader cultural formulation of ageism is fast becoming Kuhnian 'normal science' in social gerontology (Kuhn, 1970).

Our concern is to outline the limitations of the 'ageism as ideology' argument. In challenging the idea of ageism as a coherent way of linking institutional and individual concerns around later life, we do not deny that the term may still be useful. It is undoubtedly true that older people can still suffer discrimination, have their interests ignored, and can be demeaned and scapegoated as well as subjected to ridicule. All of this, we agree, should be pointed out and challenged by gerontologists (Cann and Dean, 2009). Our concern, however, is that this pragmatic use of ageism as prejudice has too easily given way to a more reified framework that risks becoming too totalising and thereby rendered less valuable for researchers exploring the impact of such attitudes and practices in the context of social gerontology and ageing studies.

\section{Ageism and ideology}

We do not intend to provide a review of all the literature on 'ageism'. This has been done already, in differing ways, and through a number of contributions, such as those by Bill Bytheway (1994, 2005), Glenda Laws (1995), Erdman Palmore (1999) and Todd Nelson (2002). Rather, as stated earlier, we wish to outline the way in which accounts of ageism have come close to identifying it as a pervasive ideology saturating society (Walker, 2012). While some authors might resist having their work classified this way, we would argue that the polysemous quality of Butler's term has created such an 'ideology effect'. With this in mind, we argue that the difficulties surrounding this 'strong' version of ageism have led to the overextension of the term to the detriment of a critical understanding of the complexities of later life in contemporary society.

\section{Ageism}

As is well known, Robert Butler not only coined the term ageism, but continued to be actively involved in discussions of it until the end of his life, in 2010 (Achenbaum, 2013). His 1969 paper outlined the discrimination that older Americans experienced in the post-war period, in terms of housing and wealth as well as in the form of institutionalised mandatory retirement. He saw the low level of funding then allocated for research into the health problems of older people as equally symptomatic. Significantly, he also pointed to the cultural construction of older people as both excluded and made 'other' to ordinary people, a process that he argued led to their further marginalisation (Butler, 1969). In an editorial published in 2009, he wrote 'that age discrimination exists advertently and 
inadvertently in personal and institutional form, and that economic and psychological factors play a major part in ageism as well' (Butler, 2009: 211).

Bytheway (2005) has made the point that there are two 'not wholly compatible' approaches to defining ageism. One concerns the beliefs held by people of all ages about the negative impact of biological ageing which relates to the fear of such ageing that develops throughout the lifecourse. The other is that exemplified by Robert Butler, which is summarised in the following way:

Ageism is discrimination against older people on grounds of age. Just as women are disadvantaged and oppressed as a result of sexism, just as black people and other minorities are oppressed by racism, so older people suffer from discrimination as a result of ageism. (Bytheway, 2005: 361)

Continuing this theme, Bytheway argues that ageism is 'rooted in the social identity of the individual, both a bureaucratically managed identity and an identity conveyed by the physical appearance of the body' (Bytheway, 2005: 362, italics in original). Paradoxically, this identity is most focused on the revelation of chronological age in both institutional as well as private arenas. A decade earlier, Glenda Laws had positioned ageism as an oppressive set of practices and saw the ageism surrounding the body as a 'surface of inscription', concluding that 'ageism is an embodied form of oppression' (Laws, 1995: 114). While there may be a number of sites in which ageism is contested, such as in employment, in the household and within the state, taken together, Laws (1995: 114) argued, they 'provide a tapestry on which ageist practices are woven'. Taking her cue from feminist and postmodern thought, Laws (1995: 118) resisted adopting an 'essentialist' position and identifying a single cause of ageism, arguing that it is important to begin at the sites at which ageism occurs and in which the aged body is created'.

Why should age become a source of oppression? One argument has been because of the costs borne by the welfare state in terms of pensions, health care and social services (Oran, 2017). Part of the argument concerning the 'structured dependency' of old age advanced by writers such as Peter Townsend (1981) was based on this very argument, as well as drawing on the implications of the 'fiscal crisis of the state' in shaping the political economy of ageing (Estes, 1986). This model has recently been updated to include the re-articulation of retirement under the politics of neo-liberalism (Macnicol, 2015). However, if retirement was once the 'tragedy' of 'forced exclusion' from work, extending working life and forcing up retirement age are now the marks of discrimination. Faced with this shift of gears, it is unsurprising that the research agenda investigating ageism has turned away from the structural position of age and work towards concerns for the social psychological and embodied aspects of ageing as the explanatory site for ageism.

Within this wider cultural framework, some researchers have identified ageism as a prejudice against our feared future selves (Nelson, 2005). North and Fiske have argued that ageism is a trans-national phenomenon whose roots are to be found in cohort competition for status and jobs, which is manifested in negative assessments of physical markers of agedness, such as grey hair and wrinkles (North and Fiske, 2012, 2013). As noted earlier, a more strongly culturalist reading is that provided by Margaret Gullette (2017a) who argues that ageist ideology is 
pervasive in all cultural forms and social encounters. It is, moreover, profoundly oppressive leading to both shame and trauma for older people based around the projected fear of old age. Decline ideologies are so pervasive, she argues, that the term ageing itself should be dropped from the lexicon of terms used to describe old age and the term ageism used in its stead (Gullette, 2017b). Ageism, like the oppressions of gender, sexuality and race, is thought to be a source of both social injustice, personal grief and psychic damage, and like sexism and racism demands a politics of identity and redress. Lynne Segal (2013) amplifies this theme by arguing that ageism implies the dependency and redundancy of older women who are seen as unable to create a positive experience of old age because of their subjection to the dominant tropes of a gendered ageism.

While we share this concern for the negative codes of ugliness and abjection through which the ageing body is often viewed (Gilleard and Higgs, 2011b, 2013), we do not see these negative stereotypes as created by ideologically shaped ageist discourses. Instead, we contend that they reflect existential and ontological concerns about ageing and decline which long pre-date any modernist or neoliberal agenda. While such concerns can be employed to promote particular agendas by both state and market actors - as in the biopolitics of ageing or the market for anti-ageing products and services - they are not constituted as such. This historical distinction goes to the root of the differences between accounts of ageism as ideology and those centring on the role of the social imaginary of the fourth age.

\section{Ideology}

In treating ageism as ideology, even in a casual fashion, the status of what constitutes an ideology necessarily comes into play. Over the past half century, this question has received considerable attention particularly from writers within the Marxist tradition (Larrain, 1979; Žižek, 1994; Therborn, 1999; Rehmann, 2013; Eagleton, 2014; Morris, 2016). Most point to its modernist and pejorative meaning as a way of accounting for dominant ideas that maintain political and social power. While the idea of ideology has acquired a rather more neutral meaning in recent years, it retains its inference of hiding or masking reality and projecting untruths. For many decades, an orthodoxy reigned of a 'base-superstructure' model of the relationship between the economy and ideas about social relations. Over time, and under the influence of different intellectual currents, the concept began to be seen as a determining social structure in its own right (Abercrombie, 1980). Perceived as a relatively autonomous discourse, it was, in Louis Althusser's famous caveat, 'only in the last instance' determined by the economy (Althusser, 1977: 113). Promoting this prioritising of ideology as discourse led to the decline of an overtly Marxist approach, with many feeling they were better served by adopting a more Foucauldian approach to politics where power was more polyvalent in its dispersion of influence and ideas (Elliott, 1986) while others attempted to combine what they saw as best in Marxist and Foucauldian approaches (Bidet, 2016).

In the absence of an accepted notion of ideology, it is interesting how the idea of ageism as a dominant ideology is considered to work. Salter and Salter (2018) have talked about a hegemonic ideology of ageing in their work on the political challenges posed by the emergence of the third age as it relates to contemporary social 
policy. They explicitly see the issues surrounding 'active ageing' through the prism of the Italian Marxist, Antonio Gramsci. This is an explicit utilisation of concepts from the Marxist canon rather than their use as a rhetorical device; a way of presenting a 'radical' critique that echoes the imagery of Marxist thought without explaining in any analytical detail its connection to social structures. The desire for ageism to carry such a critical content may be one reason why some have adopted the term 'ageist discourse' instead of 'ageist ideology' (Coupland and Coupland, 1993). Influenced by the 'cultural turn' brought on by poststructuralism, the ability to describe ageism as a dominant discourse allows for a focus on attitudes towards ageing as well as on the use of age discriminatory terminology (McVittie et al., 2003). It also permits ageist discourses to be viewed as negative in their consequences while overlooking or ignoring any seemingly positive formulations such as 'ageing well' (Angus and Reeve, 2006). Treating ageism as an ideological discourse also offers some opportunities for the production of counter-discourses such as those presented in Coupland and Williams' (2002) accounts of the different discourses surrounding women's experience of the menopause. However, as van Dijk's overview of 'critical discourse analysis' contends, it is also always important to identify the oppressive and discriminatory factors operating within specific discourses which are "promoted by elites and their discourses ... and their discursive management of the public mind' (van Dijk, 1993: 280). However, without such identification of the causal mechanisms, it is difficult to establish why such discourses exist in the first place, who benefits from them and what structures of power maintain them.

\section{Ageing and the social imaginary of the fourth age}

We have posited an alternative basis for understanding some of the issues usually subsumed under the mantle of ageism, utilising the notion of a 'social imaginary' (Higgs and Gilleard, 2016). The social imaginary of the fourth age operates very differently from the cultural field(s) of the third age, which can be understood as originating within the social changes of the late 20th century and its cultural focus on choice, autonomy, self-expression and pleasure (Gilleard and Higgs, 2011a; Higgs and Gilleard, 2014). At first sight, this might seem similar to the accounts provided by Gullette and Segal who also point to this consumerist aspect of ageism. These writers, however, provide little explanation of it other than seeing it as intrinsically connected to, and intersecting with, other forms of oppression. We would contend that much of the active 'othering' of old age in contemporary culture is closely connected to the growth of consumer markets, lifestyle differentiation and the valorisation of choice inherent in the cultures of the third age. The putative 'dark side' of old age, represented antithetically as a fourth age, serves as an amplifier of those cultures, not their product (Gilleard and Higgs, 2010; Higgs and Gilleard, 2014). The fourth age is not, however, a residual category of the third age - later life deprived of its cultural or symbolic capital (Higgs and Gilleard, 2014). It draws upon deeper traditions. The negative dimensions of old age and their capacity to serve as a social imaginary, a term adapted from the work of Cornelius Castoriadis (1987), have their origins in what he called the socio-historical 'magma' of society, magma that lie deep beneath the surface of modernity and modernisation. 
In addressing this imaginary and its connection to the concept of ageism, two points need to be made. The first is that many of the key corporeal processes of ageing are perceived as making the human body appear less attractive, lacking both health and desirability. The more individuals are subject to the processes of corporeal ageing, the more unattractive and unhealthy their body appears - reflecting what Lowenthal (1985: 129) has termed the 'almost universal' aversion to 'the look of age'. While acknowledging that these processes are also gendered and racialised, we also accept that not all bodies become less attractive or less healthy with age. Indeed, while it might be that some people acquire attractive corporeal attributes with age, such exceptional cases do not in themselves furnish convincing evidence to disprove the more general argument. Ideas of attractiveness and healthiness vary across time and place, and while the salience of such ideas may be qualified by other considerations, any particular set of vital human referents is generally made problematic by considerations of their agedness. It is old age's ontological association with a decline towards death that cuts across any simple construction of an 'ideological' basis for ageism. This is much more now, as death becomes ever-more confined to the state of agedness (Walter, 2017).

\section{Truth, reality and the 'imaginary'}

Implicit in all uses of the term 'imaginary' is a contrast with what is not imaginary; what might be thought to be real. In the Marxist tradition, as we have seen, this distinction is structural: between the imaginary (ideological) representations of social relations and the actual lived relationships of power and exploitation (Marx and Engels, 1974). Others, such as Althusser, made a distinction between 'scientific' theoretical practice and the ideologically contaminated practices of everyday life (Althusser, 1990). Rejecting any epistemological foundation for ideology, Althusser claimed that ideology is better formulated as a set of representations, which are distinguished from science whose 'practico-social function is more important than the theoretical function (function as knowledge)' (Althusser, 1977: 231). This approach has been extensively criticised, Glucksmann (1972) famously arguing that the effect of Althusser's formulation was to create a 'ventriloquist structuralism' where all the processes of society occur 'behind peoples' backs'. Ted Benton also took Althusser to task for outdoing Talcott Parsons in relation to functionalism, claiming that if Parsons's actors are cultural dopes, Althusser's agents are 'structural dopes of an even more stunning mediocrity' (Benton, 1984: 222).

The abandonment of a realist epistemological dimension to ideology has had profound effects on the utility of the concept (Morris, 2016), opening the door to more discursive approaches. As we have seen, the influence of Michel Foucault has done much to provide an entry point encouraging a more fluid concept of 'truth' as practice (Anderson, 1983). Within these alternative conceptions based upon the interplay between various forms of power and knowledge, there is not the same need for 'ideologies' to demonstrate some connection to a contrasting 'underlying reality' determining their shape and forms. The eclipse of the more traditional Marxist view of ideology as well as the difficulty of finding an adequate base for ageism to emerge as an ideology provide possibilities for the exploration of 
imaginaries as a way of understanding what has been described as ageism without thereby implying a contrasting 'real' ageing.

For writers such as Benedict Anderson (1988) and Charles Taylor (2004), the power of the social imaginary is realised through society as a necessary function. Once society expands, beyond the directly knowable bounds of small, face-to-face interactions, it becomes important to ensure common understandings and a degree of abstract predictability of social relations and trust based on common citizenship rather than shared acquaintance. Social representations serve as a common currency, transmitting shared understandings, not because of any attempt to hide the power of elites but simply to sustain the social within an ever-expanding commons. Within such expanding spaces, of course, comes greater ambiguity. As societies and the institutions of community and communication change and grow more complex, the space but not the coherence of the imaginary expands, leaving open a multiplicity of meanings and points of reference in representing social life, whose historical origins may easily be lost or impossible to root.

\section{Imagining and othering old age}

Within western culture, old age has often been represented as another country, a 'foreign' country that remains 'other' to most members of society (Higgs and Gilleard, 2014). Developing this theme it could be argued that the 'otherness' surrounding old age relates not just to its corporeal otherness: the physical differences between old and young bodies, but also to the chronological otherness of old age, its distance 'in time' from the concerns of those who embody the now, the present. This idea was well expressed by the poet May Sarton when she wrote: 'The trouble is, old age is not interesting until one gets there, a foreign country with an unknown language to the young and even to the middle-aged' (Sarton, 1982: 23). A similar sentiment regarding the distance between old age and youth occurs in the opening paragraph of L.P. Hartley's novel The Go-Between: 'The past is a foreign country: they do things differently there' (Hartley, 1961: 1). While the former writer stresses the otherness of being old, the latter emphasises the otherness of agedness itself, the strangeness of old age mixed with the old as strangers. These quotes illustrate one of the key features of the imaginary, its separation from day-to-day, face-to-face experience - in short, its fashioning of otherness. A number of other authors have explored the historical roots of this trope of 'otherness' applied to old age (Lowenthal, 1985; Minois, 1989; Thane, 2005), while still others have applied insights from post-colonial perspectives to better theorise the various 'othernesses' operative in social representations of old age (van Dyk, 2016). What such approaches make clear is that old age is represented more often as an attribute of others than as a conscious identity of the self. ${ }^{1}$

In the context of the transformation of later life and the creation of possible post-working life lifestyles, there has been a focus on 'ageless ageing', seeking as it were to draw away from the association of chronological age with infirmity and decline (Andrews, 1999; Dychtwald, 2005). This has had the consequence of throwing into sharp relief a differently residualised old age, framed as 'real' old age, which constitutes part of the social imaginary of the fourth age. Unlike the putative product of ageism, this imaginary is not so much a category or status as 
a state of being, one that is framed by frailty, abjection and the need for care amidst the indignities of old age (Gilleard and Higgs, 2010; Higgs and Gilleard, 2016). In Sarton's terms, 'real' old age is something that one falls into, rather than simply another stage of life one is travelling through (Sarton, 1996: 15). This discursive 'othering' plays a key role in situating the social imaginary of the fourth age, drawing upon already existing assumptions about the nature of 'real' old age and serving to amplify its fearfulness. It may be that these assumptions share the 'decline ideology' as articulated by Gullette and her desire to remove ageing from the gerontological lexicon (Gullette, 2017b), but to see the corporeality of old age as little more than an imagined product of culture implies a degree of social constructionism that many would find difficult to accept.

The interconnectedness of ageing, vulnerability and frailty is fundamental to the process of othering old age. Frailty has become one of the boundary issues articulating the fourth age imaginary (Higgs and Gilleard, 2015). Not only have these issues become central to the 'densification' of old age, but as Degnen (2007) points out, the experiences of corporeal morbidity that demarcate an 'us' from a 'them' serve as 'the truth' of this distinction, more than does the representation of chronological age. Within the discourses of bio-medicine, as well as those of health and social care, frailty functions as a way of alerting concerned institutions to the collapse of agency and the demise of the autonomous identity of the older individual (Gilleard and Higgs, 2010; Tomkow, 2020). When dementia is added, a further deepening of the social imaginary occurs which some have described as the 'social death' of the subject (Sweeting and Gilhooly, 1997). In addition to the dependency implied by frailty, the serious cognitive impairments constituting the various dementias limit the individual and the forms of agency and identity that can be expressed through choice, autonomy, self-expression and pleasure. Social responses to the condition often amplify this appearance of 'ageing without agency', replacing first-person narratives with those of the third person (Higgs and Gilleard, 2017). Developing this approach further, it can be argued that such 'othering' of old age is not the same as the ideological othering of an abject or precarious class, nor is it the exercise of a ruling classes' dispossession of its dominated inferiors such as contended by Georges Bataille in his original formulation of abjection and the abject classes (Bataille, 1999). Rather, it is the othering of a totalising risk, as severe as it is ill specified, that leaves no fixed position from which to offer opposition (or indeed to frame effective counter-imaginaries) - in effect to posit an opposing collective reality. If, as the literary critic, William Iser has suggested, the imaginary is realised always and only as a 'relation' or 'oscillation' between a set of triggers and their activation (Iser, 1993: 223), the suppression of any imaginary cannot simply be willed, nor can an alternative imaginary be 'induced' without denying or ignoring the salience of agedness. This has the effect of realising precisely what the cultures of the third age want to achieve.

\section{Ideology or social imaginary: a concluding comment}

This paper's principal argument is that the changes that have transformed later life, and which have crystallised in the 21 st century, need to be recognised in the conceptual tools that gerontologists use. In particular, the idea of ageism as an ideology 
which discriminates and oppresses is one that, while providing a radical gloss to arguments for social change, does not adequately address the much more nuanced issues of ageing and old age in contemporary society. Resolving the Janus-faced predicament of wanting to live long, yet not wanting to grow old, cannot simply be reduced to combating the operation of a discriminatory ideology or discourse nor even by attacking popular prejudices common in different circumstances. Taking the arguments of the fourth age further, we would contend that the imaginary is not willed into existence, and equally it cannot be willed out of existence. It possesses features that relate to the existential and ontological dimensions of human corporeality and its physical limitations. Instead, we argue, it is better to acknowledge and explore the contexts and contradictions that are presented by ageing, that exist both at an individual and at a socio-cultural level. Attempts to trace out their effects as well as to identify where their triggers can most readily be militated should not to be abandoned. Ageism as a concept can still have its uses, serving to identify examples of discrimination or exclusion in cultural participation: in the delivery of health, in employment practices, as well as in the delivery of goods and services. This aspect of ageism may be active in restricting the opportunities for individuals as they age and come close to retirement; in a sense it is this resistance to being aged that defines the cultures of the third age. But it also has to be accepted that retirement and the provisions of pensions can be seen as a positive form of ageism. How the different aspects of ageism are balanced is always going to be conditional and likely to be unresponsive to any global judgements of categorical completeness.

The idea of an overarching ideology of ageism has much less purchase as an analysis, or as the focus of critique, let alone as a framework to direct or sustain the social sciences and social policy. Holding on to it as a key concept orienting policy, practice or theory will not help us understand the challenges posed by contemporary later life, nor can it serve to underpin local or global policy initiatives designed to address the societal implications of ageing. Not that we would suggest that the concept of a fourth age social imaginary will serve instead to fulfil this expansive role. Our point is that this latter term makes more analytical sense in addressing the dilemmas facing society. By acknowledging the multiplicity of meanings that 'old age' presents, across the spaces where the state, markets and culture operate, as well as accepting the capacity for age itself to be alienating and oppressive, we are better able to explore its inherent ambiguities and limitations.

Acknowledgements. Paul Higgs would like to acknowledge the support of the University College London Hospital National Institute of Health Research Biomedical Research Centre.

\section{NOTE}

1 The relative absence of age as a source of social identity has been demonstrated by Hyde and Jones (2015: 83 , figure 5.2).

\section{References}

Abercrombie N (1980) Class, Structure, and Knowledge Problems in the Sociology of Knowledge. Oxford: Basil Blackwell.

Achenbaum A (2013) Robert N. Butler, MD: Visionary of Healthy Aging. New York, NY: Columbia University Press. 
Althusser L (1977) For Marx. London: New Left Books.

Althusser L (1990) Philosophy and the Spontaneous Philosophy of the Scientists \& Other Essays. London: Verso.

Anderson B (1988) Imagined Communities: Reflections on the Origin and Spread of Nationalism. London: Verso.

Anderson P (1983) In the Tracks of Historical Materialism. London: Verso.

Andrews M (1999) The seductiveness of agelessness. Ageing \& Society 19, 301-318.

Angus J and Reeve P (2006) Ageism: a threat to 'aging well' in the 21st century. Journal of Applied Gerontology 25, 137-152.

Appleyard B (2009) A life worth living? Quality of life in later age. In Cann P and Dean M (eds), Unequal Ageing: The Untold Story of Exclusion in Old Age. Bristol, UK: Policy Press, pp. 123-140.

Bataille G (1999) Abjection and miserable forms. Trans. Shafir Y. In Lotringer S (ed.), More \& Less. Cambridge, MA: MIT Press, pp. 8-14.

Benton T (1984) The Rise and Fall of Structural Marxism: Althusser and His Influence. London: Macmillan.

Bidet J (2016) Foucault with Marx. London: Zed Books.

Butler RN (1969) Age-ism: another form of bigotry. The Gerontologist 9, 243-246.

Butler RN (2009) Combating ageism. International Psychogeriatrics 21, 211.

Bytheway B (1994) Ageism. London: McGraw-Hill Education.

Bytheway B (2005) Ageism and age categorization. Journal of Social Issues 61, 361-374.

Cann P and Dean M (2009) Unequal Ageing: The Untold Story of Exclusion in Old Age. Bristol, UK: Policy Press.

Castoriadis C (1987) The Imaginary Institution of Society. Cambridge: Polity.

Chiu W, Chan AW, Snape E and Redman T (2001) Age stereotypes and discriminatory attitudes towards older workers: an East-West comparison. Human Relations 54, 629-661.

Coupland N and Coupland J (1993) Discourses of ageism and anti-ageism. Journal of Aging Studies 7, 279-301.

Coupland J and Williams A (2002) Conflicting discourses, shifting ideologies: pharmaceutical, 'alternative' and feminist emancipatory texts on the menopause. Discourse \& Society 13, 419-445.

Degnen C (2007) Minding the gap: the construction of old age and oldness amongst peers. Journal of Aging Studies 21, 69-80.

Dychtwald K (2005) Ageless aging: the next era of retirement. The Futurist 39, 16.

Eagleton T (2014) Ideology: An Introduction. London: Verso.

Elliott G (1986) The odyssey of Paul Hirst. New Left Review 159, 81-105.

Estes CL (1986) The politics of ageing in America. Ageing \& Society 6, 121-134.

Gadow S (1983) Frailty and strength: the dialectic in aging. The Gerontologist 23, 144-147.

Gilleard C and Higgs P (2010) Aging without agency: theorizing the fourth age. Aging and Mental Health 14, $121-128$.

Gilleard C and Higgs P (2011a) The third age as a cultural field. In Carr D and Komp K (eds), Gerontology in the Era of the Third Age: Implications and Next Steps. New York, NY: Springer, pp. 33-50.

Gilleard C and Higgs P (2011b) Ageing abjection and embodiment in the fourth age. Journal of Aging Studies 25, 135-142.

Gilleard C and Higgs P (2013) Ageing, Corporeality \& Embodiment. London: Anthem Books.

Gilleard C and Higgs P (2016) Ageing, corporeality and social divisions in later life. Ageing \& Society 37, 1681-1702.

Glucksmann A (1972) A ventriloquist structuralism. New Left Review 72, 68-92.

Greenberg J, Schimel J and Martens A (2002) Ageism: denying the face of the future. In Nelson T (ed.), Ageism: Stereotyping and Prejudice Against Older Persons. Cambridge, MA: MIT Press, pp. 27-48.

Gullette MM (2011) Agewise: Fighting the New Ageism in America. Chicago, IL: University of Chicago Press.

Gullette MM (2017a) Ending Ageism, or How Not to Shoot Old People. Newark, NJ: Rutgers University Press.

Gullette MM (2017b) Against 'aging' - how to talk about growing older. Theory, Culture \& Society.

Hartley LP (1961) The Go-Between. Harmondsworth, UK: Penguin Books.

Higgs P and Gilleard C (2014) Frailty, abjection and the 'othering' of the fourth age. Health Sociology Review 23, 10-19. 
Higgs P and Gilleard C (2015) Rethinking Old Age: Theorising the Fourth Age. London: Palgrave Macmillan.

Higgs P and Gilleard C (2016) Personhood, Care and Identity in Advanced Old Age. Bristol, UK: Policy Press.

Higgs P and Gilleard C (2017) Ageing, dementia and the social mind: past, present and future perspectives. Sociology of Health \& Illness 39, 175-181.

Hyde $M$ and Jones IR (2015) Social class, age and identity in later life. In Formosa M and Higgs P (eds), Social Class in Later Life: Power, Identity and Lifestyle, Bristol, UK: Policy Press, pp. 73-93.

Iser W (1993) The Fictive and the Imaginary. Baltimore, MD: Johns Hopkins University Press.

Kuhn TS (1970) The Structure of Scientific Revolutions. Chicago, IL: University of Chicago Press.

Larrain J (1979) The Concept of Ideology. London: Hutchison.

Laws G (1995) Understanding ageism: lessons from feminism and postmodernism. The Gerontologist 35, $112-118$.

Levy BR (2001) Eradication of ageism requires addressing the enemy within. The Gerontologist 41, 578579.

Longino CF (2005) The future of ageism: baby boomers at the doorstep. Generations 29, 79-83.

Lowenthal D (1985) The Past is a Foreign Country. Cambridge: Cambridge University Press.

Macnicol J (2006) Age Discrimination: An Historical and Contemporary Analysis. Cambridge: Cambridge University Press.

Macnicol J (2015) Neoliberalising Old Age. Cambridge: Cambridge University Press.

Marx K and Engels F (1974) The German Ideology: With Selections from Parts Two and Three, Together with Marx's 'Introduction to a Critique of Political Economy'. London: Lawrence \& Wishart.

McVittie C, McKinlay A and Widdicombe S (2003) Committed to (un) equal opportunities? 'New ageism' and the older worker. British Journal of Social Psychology 42, 595-612.

Minois G (1989) History of Old Age: From Antiquity to the Renaissance. Chicago, IL: University of Chicago Press.

Morris M (2016) Knowledge and Ideology: The Epistemology of Social and Political Critique. Cambridge: Cambridge University Press.

Nelson TD (ed.) (2002) Ageism: Stereotyping and Prejudice Against Older Persons. Cambridge, MA: MIT Press.

Nelson TD (2005) Ageism: prejudice against our feared future self. Journal of Social Issues 61, 207-221.

Neuburger J (2009) What does it mean to be old? In Cann P and Dean M (eds), Unequal Ageing: The Untold Story of Exclusion in Old Age. Bristol, UK: Policy Press, pp. 101-121.

North MS and Fiske ST (2012) An inconvenienced youth? Ageism and its potential intergenerational roots. Psychological Bulletin 138, 982-997.

North MS and Fiske ST (2013) A prescriptive intergenerational-tension ageism scale: succession, identity, and consumption (SIC). Psychological Assessment 25, 706-713.

Oran S (2017) Pensions and social reproduction. In Bhattacharya T (ed.), Social Reproduction Theory: Remapping Class, Recentering Oppression. London: Pluto Press, pp. 148-170.

Palmore E (1999) Ageism: Negative and Positive. New York, NY: Springer.

Palmore EB and Manton K (1973) Ageism compared to racism and sexism. Journal of Gerontology 28, 363-369.

Pickard S (2016) Age Studies: A Sociological Examination of How We Age and Are Aged Through the Life Course. London: Sage.

Ray RE, Cole TR, Nikander P, Marshall V, Higgs P and Andrews M (2009) Walking the walk: critical and reflective gerontology. Ageing \& Society 29, 649-658.

Rehmann J (2013) Theories of Ideology: The Powers of Alienation and Subjection. Chicago, IL: Haymarket.

Salter B and Salter C (2018) The politics of ageing: health consumers, markets and hegemonic challenge. Sociology of Health \& Illness 40, 1069-1086.

Sarton M (1982) As We Are Now. New York, NY: W.W. Norton.

Sarton M (1996) At Eighty Two: A Journal. New York, NY: W.W. Norton.

Segal L (2013) Out of Time: The Pleasures and the Perils of Ageing. London: Verso.

Snellman F (2016) Whose ageism? The reinvigoration and definitions of an elusive concept. Nordic Psychology 68, 148-159. 
Sweeting H and Gilhooly M (1997) Dementia and the phenomenon of social death. Sociology of Health e Illness 19, 93-117.

Taylor C (2004) Modern Social Imaginaries. Durham, NC: Duke University Press.

Thane P (2005) The age of old age. In Thane P (ed.), The Long History of Old Age. London: Thames \& Hudson, pp. 9-29.

Therborn G (1999) The Ideology of Power and the Power of Ideology. London: Verso.

Tomkow L (2020) The emergence and utilisation of frailty in the United Kingdom: a contemporary biopolitical practice. Ageing \& Society 40, 695-712.

Townsend P (1981) The structured dependency of the elderly: a creation of social policy in the twentieth century. Ageing \& Society 1, 5-28.

van Dijk TA (1993) Principles of critical discourse analysis. Discourse and Society 4, 249-283.

van Dyk S (2016) The othering of old age: insights from postcolonial studies. Journal of Aging Studies 39, 109-120.

Walker A (2012) The new ageism. The Political Quarterly 83, 812-819.

Walter T (2017) What Death Means Now: Thinking Critically About Dying and Grieving. Bristol, UK: Policy Press.

Wilkinson JA and Ferraro KF (2002) Thirty years of ageism research. In Nelson T (ed.), Ageism: Stereotyping and Prejudice Against Older Persons. Boston, MA: MIT Press, pp. 339-358.

Žižek S (1994) The spectre of ideology. In Žižek S (ed.), Mapping Ideology. London: Verso, pp. 1-33.

Cite this article: Higgs P, Gilleard C (2020). The ideology of ageism versus the social imaginary of the fourth age: two differing approaches to the negative contexts of old age. Ageing \& Society 40, 1617-1630. https://doi.org/10.1017/S0144686X19000096 